\title{
Mothering and 'insider' Dilemmas: Feminist Sociologists in the Research Process
}

\section{Linda Cooper and Chrissie Rogers}

Anglia Ruskin University; Aston University

\section{Abstract}

This paper is about care, insider positions and mothering within feminist research. We ask questions about how honest, ethical and caring can we really be in placing the self into the research process as mothers ourselves. Should we leave out aspects of the research that do not fit neatly and how ethical can we claim to be if we do? Moreover, should difficult differences, secrets and silences that emerge from the research process and research stories that might 'out' us as failures be excluded from research outcomes so as to claim legitimate research? We consider the use of a feminist methods as crucial in the reciprocal and relational understanding of personal enquiry. Mothers invest significant emotional capital in their families and we explore the blurring of the interpersonal and intrapersonal when sharing mothering experiences common to both participant and researcher. Indeed participants can identify themselves within the process as 'friends' of the researcher. We both have familiarity within our respective research that has led to mutual understanding of having insider positions. Crucially individuals' realities are a vital component of the qualitative paradigm and that 'insider' research remains a necessary, albeit messy vehicle in social research. As it is we consider a growing body of literature which marks out and endorses a feminist ethics of care. All of which critique established ways of thinking about ethics, morality, security, citizenship and care. It provides alternatives in mapping private and public aspects of social life as it operates at a theoretical level, but importantly for this paper also at the level of practical application.

Keywords: Education, Feminism, Insider, Care Ethics, Mothering, Reflexivity.

\section{Introduction}

There is a growing body of literature which marks out and endorses a feminist ethics of care. All of which critique established ways of thinking about ethics, 
morality, security, citizenship and care (Held 2006, Robinson 2011, Tronto 2011). It provides alternatives in mapping private and public aspects of social life as it operates at a theoretical level, but importantly for this paper also at the level of practical application. This paper is about care and insider positions within feminist research, and we want to ask questions about how honest, ethical and caring can we really be in placing the self into the research process. Should we leave out aspects of the research that do not fit neatly and how ethical can we claim to be if we do (Coy 2006, Rogers and Ludhra 2011)? Moreover, should difficult differences (Reay 1996, Rogers 2013a), secrets and silences that emerge from the research process (Ryan-Flood and Gill 2010) and research stories that might 'out' researchers as failures (David et al. 1993, Woodthorpe 2011) be excluded from research outcomes so as to claim legitimate research? This paper adds contribution to the debate on feminist research methodology, as we address these questions within sociology as part of breaking with the silences. Drawing on literature and methodologies exploring feminist ethics of care within the research process (Noddings 2013, Rogers 2013a) we acknowledge aspects of mothering from a dual and relational position. Findings from two different research projects have highlighted the on-going persistence of insider research often considered methodologically weak or soft. Different, but interrelated findings highlight how prior lived experience of our participants' narratives presents a messiness to be explored within qualitative research. This paper seeks to inform various characteristics of the insider role within the research process itself and highlight the visibility of 'insider' research as a valuable and caring methodological tool, rather than apologise for any lack of hypotheses and quantifiable outcomes.

In studying predominantly women's lives, we have found broadly feminist theory and methods to be valuable in the exploration of mothering and education (see for example, McNay 1992, Reay 1996, Walby 1999). The lived experiences of having to make choices around education, work, mothering and family often comes from mothers and not from male relations (Walkerdine et al. 2001). Moreover, Walkerdine and her colleagues argue that the hopes and ambitions of women are driven by the social class system. This adds a further dimension to our research in the exploration of the dyadic, inter-family relationship of mothers' involvement in their daughters' higher education and decision making processes in mothering children with SEN when 'care work' is considered above the 
normative expectation. Since these are female discourses here, and politically we are driven to hear women, it is appropriate to embed this paper in feminist research, despite the different forms of feminism, which consists of commonalities, contradictions, compromises and alliances (Letherby 2003; RyanFlood and Gill 2010).

\section{Defending the integrity of insider research}

Despite criticisms around research that does not claim to be objective, the self and the position of the researcher is heavily scrutinised within the feminist qualitative research position (Oakley 2010, Ribbens McCarthy 2013, Woodthorpe 2011). Drawing on two sets of data on unrelated mothering issues that highlight related dilemmas, this paper argues that in sociological terms, the 'insider' role is a powerful reflexive position used to gain deeper engagement and insight into participants' understanding of lived experience, which has always been part of the nature of qualitative research. We question here the 'insider' status in qualitative research and how studies within the field of education and mothering often assume this position. Therefore, the starting point for us as mothers who carried out research, was the personal experiences of other mothers in the South of England in particular circumstances. For the purposes of this paper, we want to unpack the complexities of the process of attempting in the first instance to remain on the outside of our participants' narratives, while being engaged, personally and professionally (Coy 2006) in discussing the emotional work of mothering (Reay 2004). In our research we looked at mothering, either via access to higher education (Linda) (Cooper 2013), or children who were identified with 'special educational needs' (SEN) (Chrissie) (Rogers 2007a, b, 2011, 2013a, 2013b). Hence, we engaged with education stories within a mothering narrative. For example, we wanted to know how it felt to experience (or not) higher education (see also David 2009), or how it felt to mother a child who behaved outside normative education expectations within an 'inclusive' education system (see also Cole 2004). Education, expectation, exclusion, achievement and access were themes that cut across our narratives (Gillies, 2007). For this paper we address feminist methodological nuances that played a part in researching from the assumed position of the 'inside', (David et al. 1993, Gill 2010, Reay 1996, Ribbens 1998). Research inquiry often begins from the position of what is known (Ribbens and Edwards 1998), and that is the case for both datasets used here. Presentation of both research projects at various conferences has highlighted 
tensions that exist where insider research has been considered indulgent or privileged. This unearths a gap in methodological issues surrounding the insider researcher, which we discuss. As researchers, we believe that sociology is a living, organic discipline and the crossover between our experiences and those of our participants adds depth, rather than dilutes our position. Methodologically the feminist qualitative researcher often wants to explore and understand why and how things happen through a sense of empathy, observation of real life situations, listening to and telling stories (Ryan-Flood 2010; Ribbens McCarthy and Edwards 2011). This paper explores the methodological questions that are asked when researchers identify with their participants' narratives due to their insider status. It draws on research where both researchers are mothers who were able to identify with and care about their participants' personal circumstances. We aimed to acknowledge the changes for women as actors within wider educational discourses of higher education and SEN. Importantly this paper examines how an 'insider' role can support the interview or research conversation, in this case understanding mothering through the lens of intersectionality - class, gender and disability, but that this 'insider' status does not necessarily pan out in the way we might like it to, leaving questions unanswered about our research relationships. We acknowledge the possibility of over complicity in 'insider' research, the danger of the assumption of sameness gives rise to the potential for misinterpretation (Sanger 2010). Our sociological feminist position is to uncover common educational hurdles and render the familiar strange, but from a caring position. We use reflexivity in the research journey, not only to engage in a deeper understanding, but with the awareness that the interview process is largely a reciprocal arrangement and always relational (Hertz 1997, Ribbens and Edwards 1998, Letherby 2003, Woodthorpe 2011). Reciprocity and reflexivity is important in the trust element in qualitative methods between interviewer and interviewee. Reflexivity is a useful research tool to identify uniqueness within social research that has become more aware of the impact of individual experiences (Beck 2002). By making the private public, in this instance the complexity and emotional work of mothers, we are able to make a claim to insider status, but we recognise that this is, at times, messy and uncomfortable. We encountered women who had some experiences in common with us and we had lived through aspects of the experiences we were exploring, in our particular way, but importantly for the participants, through our lived experiences as mothers. This is not unusual in mothering (and non-mothering) 
feminist research, as for example, Ribbens (1998) discusses motherhood autobiographically where she considers the difficulties of hearing her voice amongst an array of the other mothers' voices, Letherby (2000) talks about ethics and 'dangerous liaisons' in auto/biographical research and Asher (2011) talks candidly of the deconstruction of her feminist self and the overbearing responsibility she felt on becoming a mother. Research within a feminist framework might also (but not necessarily) reflect feminist or care ethics, in a more nuanced and theoretical way than we can discuss here, but it is in this context we understand that we have a sense of duty regarding all research participants, and that participation within the research process is reciprocal (Lynch et al. 2009, Philip, Rogers and Weller 2013, Puig de la Bellacasa 2012). As suggested by Ribbens McCarthy and Edwards (2011), social scientists vary in their understandings of the interdependency of the public and private within insider research, leading us to interpret the association we established as researchers with our participants through the concepts interactive, collective and friendship. In advocating reflexivity Letherby (2003) argues that respondents' own social reality and that which they share should be for the benefit of all involved in the research, not just for an academic outcome or audience indicating a caring and meaningful process. In this way, she outlines that many participants in research are not actually given the opportunity to participate, only to respond. We further agree with Letherby's (2000: 94) advocacy of the individual experience, that 'to disregard the subjective is to downgrade the personal'. Birch and Miller (2002) reflect on the ethical responsibilities and the need for research to be a reciprocal, positive activity. The importance of the 'relationship' aspect of the process has come out of the development and recognition of our many selves (Reinharz 1997) that will be discussed in more detail below.

\section{Feminist work in process}

Our particular research process

Qualitative interview data from research carried out in the South of England and critical reflection inform this paper. One examined mothering and the conflict and contradiction within education for children identified with SEN (Rogers 2007a, b, $2011,2013)$. The other examined generational differences between mothers' and daughters' access and aspirations to higher education, which drew upon a 
personal education journey as a mature student, a mother and a daughter (Cooper 2013).

\section{A feminist framework}

For both research projects the use of a feminist methodology enabled reflection on particular aspects of women's lives 'from a particular theoretical and methodological perspective' (Mauthner et al. 2002: 3). Critically Birch and colleagues talk of the 'interplay' between public debates and women's private experiences, which is crucial in thinking through the private and public lives of all the participants. Ribbens and Edwards (1998) specifically highlight the complications, both of women's private experiences of public issues and the sensitivities required to remain faithful to the domestic, personal and intimate narratives of their participants, whilst translating them into public knowledge to further the understanding within social research. A central theme that emerged during their research was the difficulty in separating mothering discourse from the centrality of caring and subsequent emotional narratives. Ribbens McCarthy and Edwards raise the issue of motherhood as being a core identity for many women, which 'closely determines their moral and social standing' (2011: 134). This philosophical argument of humanity and its role for mothers interplays with a caring discourse and the changing role between generations, and in response to dependency and interdependency (Rogers 2013b; Cooper 2013).

\section{Doing Feminist Methods}

As suggested, feminist methodology is always going to play a key role in understanding generational differences in social policy and educational access, but this opposing dialogue highlights an area that requires critical engagement in order to inform current gender related issues. But in thinking about the process, when it comes to a feminist interview, we agree that whilst unstructured approaches work, we always attempted to keep the interview chronological, thematic and interactive (Ellis et al. 1997: 121) which we consider a meaningful way 'for getting in-depth and intimate understandings of peoples experiences'. This type of interviewing 'requires considerable time, multiple interview sessions, and attention to communication and emotions' (ibid). Moreover it is evident with regards to the interviewing process the interviewer and interviewee are shaped in some way by the research journey (Alldred and Gillies 2008). As an interesting methodological point, as mothers (and feminists) we were able to empathise 
with our participant responses, with their anxieties and/or excitement for their children. Many of our participant mothers gave real consideration to their answers, suggesting that we would understand 'where they were coming from' or 'had been there too', sharing concerns as mothers. We have found (not without problems) that we have been able to explore our research through being able to switch roles as a mother and researcher (Rogers 2003), and Letherby (2003) suggests that participants who can identify with their interviewees through a shared knowledge can feel a sense of security to participants who, more often than not, were unfamiliar with academic research processes (Rogers and Ludhra 2011). Crucially more than anything else, we wanted to know what their experiences were, but their role differed from interview to interview in how we interacted with them. As researchers our identities have been shaped to some degree by these different, but not mutually exclusive roles. Through the interview process and understanding people's actions and past experiences, we hoped to achieve meaning making by 'connecting and seeing the consequences of actions and events over time' (Denzin and Lincoln 2005: 656). This is particularly relevant to life course research. Using narrative enquiry we were also able to reflect on their emotions, thoughts and actions to inform our research (Denzin and Lincoln 2005). Narrative analysis can be envisaged as too tidy and refined through the process of disseminating life histories and making them 'fit' into the theory, yet the autonomous stories and experiences also allow a 'continuous redefinition' and renegotiation of the theoretical basis of this research (Becker 1982: 58). Critically Reay and Arnot (2007) consider that family and social identity have a strong impact on young people's lives, choices and pathways, and in the case of both generational research and disability research this is certainly the case. Moreover our research is contextualised, more generally, by reflections from our own background in the form of autobiographical interludes (Rogers 2003, 2009a,b). This style inherently brings subjectivity to research as both mothers and researchers, and we are not suggesting that the auto/biographical account, without reflexivity and positioned in a wider social context, is sociological (Oakley 2010, Woodthorpe 2011). But we consider the findings of our research with a duality of insider/outsider status, to understand the research from both an intrapersonal and interpersonal position. By observing the research through different analytical lenses, participants' narratives can be considered from both insider and outsider perspectives, by moving in and out of both roles. This includes the need to be reflexive and 
engage with the sometimes chaotic nature of qualitative research, contextualized by listening to personal experiences in order to understand individual agency (Hoskin 1990). It is also understood that the unique nature of individual life stories makes it impossible to truly be an insider and in a professional sense the researcher will always remain on the outside, looking into other people's lives (Coy 2006). The participants' narratives can be considered from the insider/outsider perspective by moving in and out of both roles. The personal nature of qualitative research means each encounter is constructed or reconstructed specifically to the discussion with each participant.

\section{Researchers as 'insiders' - interactive interviews}

Despite the different research areas, a key term for both of us was 'lived experience'. We both have familiarity within our respective research that has led to a mutual understanding of having 'insider' positions. For example, personal struggles around raising a disabled daughter, intersected with sociological knowledge, meant experiences provided an 'insider' role. Moreover, an 'insider' as a mother and a mature student is a powerful driver in understanding the complexities and barriers to accessing higher education. Here we can see interactive interviewing illustrated with Tia, a 42 year-old university academic. As an insider to higher education and as a mother, Linda was party to Tia's story as this aspect of her life history, in her description of her return to education with young children is explored in the assumptions made about their collective experience. As Tia says, 'It's the juggling with the kids, which I'm sure you've been through. It's getting them from one place to the other, to get to university do your essays in the evening and try and be superwoman at home'. Tia included Linda in her conversation to acknowledge her experiences, whilst capturing this memory of her understanding of the pressures of studying with a young family. Tia also expressed very clearly how she tried to 'do it all'. However unknown to the participant Linda was able to draw parallels to her own background.

Elle, another of Linda's participants discussed her parent's divorce and this drew uncanny similarities to her own background as seen 'when my Mum and Dad got divorced she [Mum] had very few rights, she struggled to keep the children, she got nothing financially out of the settlement, he was more powerful than her financially and therefore he appeared to have more rights'. This provides another lens on the 'insider' position, where empathy and understanding is inherent in 
the interactive interview. Elle's narrative is perhaps the most poignant and explicit example Linda had of her 'insider' status:

L: [. . . ] if you'd have wanted to go to university or given your family situation at the time [. . .] would that have been an option or would it have still been about the money then?

E: I think it would probably have been about the money as well [. . .] my Mum probably would have had to support me and she wasn't in a position so I didn't even think about it to be honest.

L: Same with me really, it's really uncanny actually, the things you're saying.

E: Sorry! (both laugh)

L: No it is, really [. . .] I just couldn't have put it on my Mum to come home and say oh I'm going to university [. . .] I just don't think I could have done it. You know I went straight out to work at $16 \ldots$

E: Like me.

L: [. . . ] You know, it's really uncanny.

E: and my Dad wasn't around... .

L: No, neither was mine...

$\mathrm{E}:$. . . and he barely gave shoe money, so there was no way he was going to help and my Mum did so much that I would never, even if I had wanted to, I would have said so.

L: Yeah, my Dad moved away and my Mum did everything and we didn't get anything from Dad [. . .] It's so interesting, the similarities.

This extract was a single exception in all of Linda's research transcripts that engaged her in deep rooted and personal issues. Sharing insider information can be a deliberate way to remove power relations between participant and researcher, allowing narrative to flow. To suggest this discussion did not take place, places no value on its content or to completely omit its inclusion from data analysis would be ethically unsound and lack care. As it happens, Elle was particularly nervous, having never been involved with any form of research before this interview. The more conversational and caring interviewing in this instance meant that Linda shared the commonalities of their backgrounds to enable Elle to relax and share her experiences, stories that otherwise might not have been heard, and yet it was more than just her story. Linda involved herself in this research process not simply as a tool to gain more information and place Elle into a more secure position. She actually was an integral part of the 
narrative. However, the personal nature of the conversation did not compromise the professional nature of the task in hand. This interactive relationship is more than simply a research one and so the 'insider' status prompts a conversational type interaction, suggesting that you, as the researcher, at the point of the interview, are regarded as a 'friend', which as discussed within this paper can be problematic, morally and personally.

So as the qualitative researcher finds her way through this emotional encounter, there emerges commitment to different 'membership roles' during the research process (Rogers 2003), for example, as mother, researcher, acquaintance, colleague, confidant, friend (see below for further discussion), and that may change at different stages throughout. Importantly, as Adler and Adler (1997) found in their research with children, commitment to the 'parental membership' role with their own children, who were part of the research cohort, was stronger than any other membership role. At times this role impacted on them and those around them negatively, (both in the family and those being researched). Occasionally they had to discontinue working with respondents due to their commitment to this parental membership role if problems occurred in relationships between other child participants and their own. In a different but still challenging way, O'Brien (2010) too discusses membership roles and the difficulty of such role differentiation, both practically and morally, in making sense of her semi covert position as a female door worker in a night club. This was highlighted when faced with a critical incident to do with a vulnerable young female clubber and her role in the process. A window into the dilemma is exemplified in her field notes as she had to remove the young woman from the nightclub where she was employed and where she carried out her ethnographic research. Here she tells of how she tried to explain to her colleague Carl (a male security officer). I explain to Carl that she is not in a state to get herself home safely; she is vulnerable, so if we have to eject her from the club then we need to find her friend. He replies, 'No just leave it. She's not our problem now. They're not our problem when they're outside'. She is escorted out of the building alone and I am sent back to my position (O'Brien 2010: 118). While this particular moral dilemma might be more problematic and have more serious consequences than ours in talking to mothers, the idea of understanding roles, the blurring of being an insider or outsider and of having a moral compass is not so different. We did initially believe we could separate our different membership roles clearly 
(see also Woodthorpe 2011), but as our research progressed it became evident this was increasingly difficult as our roles (or selves) were intricately woven into the research process. Like O'Brien (2010) and others, we sometimes questioned our research self.

Optimistically, it is clear there is knowing interaction going on in the way of sharing experiences as one of Chrissie's participants, Lynne, actively asked her about her personal history during the interview.

L: What's your daughter's. . . [IQ] do you know?

C: She's actually got an IQ of about 70.

L: 70 ?

C: That's quite difficult to cope with... you just think... well I still believe that. . . I'm not sure about the IQ test...

L: Oh yes...

C: And I don't know whether there's a certain amount that I don't want it to be right, or whether scientifically think that it's... you know [...]

L: Yes but that's not a cause and effect. She hasn't got any other diagnosis other than that?

C: Dyslexia, dyspraxia...

L: She's not on the autistic spectrum as far as you know?

C: No that's never been discussed [...]

L: Oh right.

C: To be honest that's one of the things that's held her together is she's quite sociable, but she's also had a lot of bullying, and been crying at home in bed....

L: Mmm...Mmm...

It is clear that there is a mutual interactive process going on; even to the point, where sometimes it could be difficult to identify who is the researcher. But as we found above, gaining qualitative research data is always a process of personal interaction, and this is regardless of being party to a particular social circumstance. However, in engaging with these types of interactive and emotional interviews it can be difficult to relive certain aspects of our past, as in the interview process we might be reminded of our daughter's disability or caring for our ageing mother. While this might be difficult for the researcher at times, it could be argued that the 'insider' status enables the participant to make sense of her own story in the telling and re-telling as part of a dialogue. Questions for 
both of us were answered during the data collection as it was clear we acknowledge each other's stories within the interview process. These types of interactions underline the fact that the researcher is compelled to questioning her own history, her moral position and place in the research process. This can be painful, emotional and provocative, and can then leak into life outside that of the researcher role. Moreover in this context and discussing a reflexive process, we highlight the 'insider' position and researcher emersion in attempting to explore reciprocity when a participant enquired into our experience further. This approach with participants also enables the studies to take place within a feminist research framework, where consent and understanding is gained but importantly often renegotiated (Miller and Bell 2002), particularly in light of evidently personal and sometimes difficult narratives. Hence during an interview with Brenda, a mother who has mild cerebral palsy as well as a disabled son, Chrissie felt it important to share her experiences not because Brenda asked her, but because she sensed it as a way to ease the interview process for Brenda, in a caring manner, not dissimilar to Tia with Linda above. As a result of the interaction (Brenda's impairment - speech and language difficulties, and her emotional response to talking about this emotive recollection about her son) it was not always easy to understand Brenda and she was upset at times. Below is a vignette taken from Chrissie's research diary and interview transcript in the telling of a story as it gives the reader a flavour of the interview, which, we would argue is part of a reflexive process; a process where we constantly negotiate and re-negotiate ourselves and our participants' relationships. In telling this story, it is evident there are difficult narratives to share.

Brenda thinks for a moment and then explains 'They're alright [other parents] and not that sociable', she stopped to think and seemed quite angry. 'But they get homework [the other children] nearly every day, and [my son] doesn't get hardly any'. She paused and then said despondently 'He still can't write his name and they're all writing little sentences'. 'I know' it was my turn to pause and I really felt for her. I could totally understand why she was so frustrated and emotional. I wanted to share my difficulties in an attempt to help her to see she wasn't alone in those feelings. I began 'I can sit here and reflect on all of that because [my daughter] is 14 and a half now and I remember what that was like. There wasn't an obvious problem', I paused, 'She's progressing and I'm sure that she'll be ok but I know it seems hopeless at your stage because kids of his age 
just go at such a pace and it hurts'. I pause again not sure if this was for her benefit or mine.

This vignette reveals that interviewing participants who have some similar experiences can lead the researcher down a path that was not necessarily anticipated emotionally. But it also highlights vulnerability of the participant and the researcher as they both negotiate how to respond to their own emotions in the telling and retelling of a story. In such an emotional interaction, we understand research relationships and encounters are unpredictable and they can sometimes reveal contradictions and blur research relationships. Furthermore, after all of this, we leave the field, and indeed our participants. These emotive encounters are recognised in Woodthorpe's (2011) research as she left the field thinking that the messy and emotionally provocative data collection about death and dying was over, and therefore her feelings could be shelved as she entered the analysis stage and began to put 'pen to paper'. I expected that the period after the field would be one of remote scrutiny, thinking through theories and applying them to data I had generated. [. . .] I had not fully appreciated how challenges related to detachment could continue to arise after the empirical data generation period (105). There are indeed problems of 'insider' status and emersion into the field that can cover up or assume knowledge between the researcher and her participant and provoke emotionality that was unexpected. Both our stories emerge through personal struggle, political awareness and listening to the lives of mothers that has influenced and still is influenced by a feminist position, and still emotional commitment during and after leaving the field, can blur research and relationship boundaries.

\section{Participants as 'friends' - a complicated relationship?}

In moving on from the blurry nature of a research relationship the participant's knowledge of our identities as mothers meant that the interviews were often interactive and conversational and brought a new perspective to the research; that the participants regard the interviewer as 'friend' and therefore the connection went beyond the researcher - researched. This is expressed through the emotive nature of mothering, which enabled the participants to immerse themselves in a conversation, knowing (or assuming) that we had first-hand experience of their stories, we had our own mothering stories and that these were often peppered with differences and difficulties also. During analysis of the 
data, we recognised that the welcome we received from many of our participants often meant that researcher/participant relationship became a more personal one, albeit on a more often than not superficial level. For example, Chrissie experienced this blurring of the researcher/friend first hand, when Karen, $a$ participant from her research, called six months after their interview to 'catch up' (Rogers 2003). In response to this Chrissie felt some discomfort with this leakage into her 'private' life as Karen had positioned herself as an 'insider' to Chrissie's family relationships in asking how her daughter was and if she wanted to meet for coffee. It seems insider (and arguably caring) research might not smoothly untangle the research/'intimate' relationship which could be problematic for the researcher. Moreover, although Robinson (2011: 29) says, many things about feminist care ethics and human security, there is a commitment to moral issues, particularly in relation to real lived experiences and a reconceptualisation of how we understand the public and private spheres, which we can understand in the field as well as theoretically. Such relational interpretations and understandings are often inherent in feminist narrative enquiry but we might question then who is this 'insider'? One of the problems of being an 'insider' and then having experience recognition between the participant and the researcher, is further illustrated here. Lynne talks about her difficulties in dealing with 'experts" language and tells Chrissie, 'I can remember saying to the speech therapist it's as if I'm talking a different language and he has to repeat it because he's translating it. "Know what I mean?" "Yeah..." I reply.' So Chrissie and Karen had this recognition between their own experiences, as we saw above, yet this is not always helpful in the research process. That said it is possible that many of our participants would not have got to the point of a detailed narrative if we were unable to empathise with their story. Indeed, while we recognise the merits of the 'insider' in terms of being researchers we always remain outsiders to the participants' lives and stories.

Participants always retain the right to withhold any information they deem too sensitive or personal. Although participants are already sharing personal information, knowing how far to pursue the insider role is an important aspect of researching within a feminist framework (Letherby 2003). Further insights from the field, explore the balance of the insider/outsider role here as Chrissie says in her field notes from a conference for parents with children with SEN, 'I was torn between keeping quiet and being in the role of 'researcher' as an outsider, and 
actually being a participant. At this point below Chrissie decided to participate and said: 'My child had been excluded in mainstream secondary school from certain activities such as assemblies, and a day trip.' I recalled 'No one from the school had thought it necessary to involve me in the decision as to whether she should be included in these activities or not'. Others guffawed at what each of the parents were saying and nodding in agreement. This group discussion wasn't only charged with anger and frustration but with obvious pain as one mother was trying to hold back the tears whilst she spoke'. That night on reflection Chrissie recalled that she did not feel much like a mother and in some way disentangled herself from the difficulties as if she had learned to be a distanced researcher while sharing her experiences. Are we supposed to disentangle ourselves as caring researchers (caring for ourselves, as well as our participants?) Again, we are led to thinking about how removed our story, our history, our emotions can be from a feminist research process.

\section{Conclusion}

While there is increasing literature on auto/biography, biography, autoethnography (Plummer 2009, Ellis and Bochner 2000, Oakley 2010), and less than conventional ways of writing social research there is still relatively little on the actual practicalities of the problem of managing the self when close to the research material (Woodthorpe 2011). As we suggest throughout this paper, if we fail to include and engage with both the provocative or everyday narrative, we are in danger of becoming ethically unsound or devaluing voices that engage with the personal and then potentially care less. We advocate insider research as a positive approach to the feminist, ethical, caring, qualitative methodology; to avoid involvement with data in this way could indeed discourage new feminist scholars to carry out this type of research. We do acknowledge that the insider approach is appropriate only in particular circumstances and highlight the tensions of where to place the self when emotionally close to research narratives. We not only mean experientially, but specifically how the researcher negotiates the close personal relationships with the research participants (Coy 2006).

The use of different lenses, insider-outsider, mother-daughter, access-barriers, allowed us as researchers to pose questions and share narratives with our participants, to provide depth and breadth to our research projects that explored 
real life difficulties and dilemmas. But it also went beyond these angles. How can we really know the impact, as researchers, we had on introducing our participants to a dialogic narrative about aspects of their personal life? We cannot. Yet we can know and understand that changes occurred during the research process for our participants. We were reflexive and caring so were our participants at times. This change making narrative for our participants and for us as researchers is feminist research. We have introduced stories with mothers and about mothering and by virtue of our biographical interludes we are included as mothers within this process. The story unfolds whereby some of our participants react to us in the interview process often not only as interviewees, but as confidants which we describe as interactive. Indeed we sometimes share our collective experiences and our role as a researcher blurs into that of motherresearcher. In turn, despite often engaging with highly emotive subjects our participants felt confident sharing this information with us. This highlights the importance of reflexivity within this research process and how the outcomes become beneficial in studies which embrace a feminist methodology, in the interests of both the researchers and the respondents. The often subjective and personal nature of insider stories means that it comes under scrutiny as compromising academic rigour. Like all feminist qualitative sociologists, we are engaged in making the private public. We purport the view that closer engagement is often the most beneficial way of making participants comfortable during the interview process.

Knowledge-sharing encourages the research to become a two-way process and enables us to maintain a duty of care as feminist researchers to our participants. With this integrity in mind, our involvement as insiders mean we were often welcomed into women's homes and life histories. We have outlined our experience recognition and the ways in which the participants' knowledge of our position means they often place us as 'friends'. Others regarded us purely as researchers and outsiders. We approached the participants with individuality, care and respect, to give each of them as much control and comfort as possible during the interview process. Notwithstanding these areas of interest, we are aware of the necessity to respect and judge our engagement as insiders, with complete ethical transparency, yet delineate a fine line as outsiders. Ultimately we are outsiders to all of our participants' experiences, and it is likely we will never be 'friends', yet it is our contention that insider status has enabled our 
participants to share detailed and personal stories with a sense of reassurance. We have examined here the dilemmas of partiality and the necessity to have to sometimes adopt different strategies to achieve these narratives. The use of two different research projects allowed us as researchers to consider methodological sameness and differences having both used an insider approach and where both have been previously judged as taking a privileged or sentimental stance. Insider research in itself is a widely acknowledged paradigm within qualitative research, but the honesty of the negotiation of the self in such methodology is often underplayed, for fear of compromising academic integrity. As it is 'an ethic of care focuses on attentiveness, trust, responsiveness to need, narrative nuance and cultivating caring relations' (Held 2006: 3-4) all of which we aspire to in the research process. If we are to immerse ourselves as feminist researchers, it is imperative that we hear all voices and such work surrounding the 'self' and the private is accepted as caring, professional and academic.

\section{Acknowledgements}

We would like to thank the anonymous reviewers for their insightful comments. They have made the paper a much stronger one as a result of their engagement. Moreover, we thank our participant mothers for being a part of this feminist process. All the participants' names used are pseudonyms.

\section{Notes}

We fully acknowledge that many fathers take a full and engaged role in educational and parenting roles, but for the purposes of this paper we are focusing on mother's perspectives only. Feminist sociologists such as Oakley (1981, 2010) Reay (1996) and Ribbens (1998) remain important commentators and actors in the art of accessing, interpreting, analysing and theorising research participants. Standpoint feminist Hartsock (1998) and those commenting on it as Harding (1986, 1991, 1993), Smart (1990), Skeggs (1997) and McRobbie (2009) argue, it is not simply the experience of women, but that the experience comes from struggle with oppression. We see that Harding (1991, 1993), Smart (1990) Ryan-Flood and Gill (2010), Woodthorpe (2011) and McRobbie (2009), amongst others, recognise the reflexive journey writers go through in a feminist research process and it is not always the case whereby a researcher can attribute a type of feminism within which they feel comfortable with and therefore settled. For example within a feminist ethics interpretation on-line spaces such as Mumsnet 
(2013) a blogging site tagged 'By Parents, For Parents', has opened a space for mothers with intellectually disabled children, or those identified with 'special education needs' (SEN). This is largely due to problems around dealing with, discovering your child's impairment, 'special education', education professionals, inclusion and assessments (Rogers 2007, forthcoming). As it happens mothers are blogging about their everyday lives, which has become a pastime for some in gaining answers to questions about their children generally, but it has also been suggested it is a space to care (Doucet and Mauthner 2013). Although engaging in critical debate Doucet and Mauthner (2013) do ask questions of 'mommy blogging' in relation to this 'caring space' as they ponder the separation of care, work and consumption practices, as well as question how integrated or distinct from care work it is (ibid: 103). Nevertheless people in different blogging and internet forums come together to discuss issues virtually and often with a view to support. This is important here, because as feminist researchers we now find ourselves in different caring spaces. And not all are comfortable or indeed knowable.

Space does not permit, but we also wanted to recognise that the work of Bourdieu is useful to consider a reflexive approach in qualitative research. Structure and agency can be understood through the power relations of the interviewer/participant within the research interview, alongside personal agendas of cause and effect for participation within such research. Bourdieu (1984: 1) for example suggests, '[i]n choosing to study the social world in which we are involved, we are obliged to confront it, in dramatized form [...] a certain number of fundamental epistemological problems, all related to the question of the difference between practical knowledge and scholarly knowledge, and particularly to the special difficulties involved first in breaking with inside experience and then in reconstituting the knowledge which has been obtained by means of this break' Bourdieu here urges us as researchers to understand the impact of the personal in order to reconstruct the scholarly and clearly underlines objectivity between the field and researcher (Grenfell and James 1998). In approaching the research process, the doxic or common approach to the interview is often as detached outsider. A reflexive approach to research challenges the doxa and differentiates the structure in which the data is gathered (Deer 2008). There are implications to this style of research (Grenfell and James 1998), but working in a reflexive style also highlights practical and 
theoretical concerns that need to be addressed and are often misrecognised as lacking in epistemological substance (Robbins 1998). That said we are working within a feminist position here.

\section{References}

Adler, P., and Adler, P. (1997). Parent-as-researcher: the politics of researching the personal life. In: Hertz, R., (Ed), Reflexivity and voice. London: Sage.

Alldred, P., and Gillies, V. (2008). Eliciting research accounts: re/producing modern subjects? In: Mauthner, M., Birch, M., Jessop, J., and Miller, T. Ethics in qualitative research. London: Sage.

Asher, R. (2011). Shattered: modern motherhood and the illusion of equality. London: Harvill Secker.

Beck, U. (2002). Individualization. London: Sage.

Becker, H.S. (1982). Tricks of the trade: how to think about your research while you are doing i.t London: University of Chicago Press.

Birch, M., and Miller, T. (2002). Encouraging participation: ethics and responsibilities. In: Mauthner, M., Birch, M., Jessop, J., and Miller, T. (Eds). Ethics in qualitative research. London: Sage.

Bourdieu, P. (1984). Homo Academicus. Cambridge: Polity Press.

Cole, B. (2004) Mothers-Teachers: Insights on Inclusion London: David Fulton Publishers Ltd.

Cooper, L. (2013). Women and higher education: perspectives of middle-class, mother-daughter dyads. Gender and Education. Vol 25, No 5, p. 624-635.

Coy, M. (2006). 'This morning I'm a researcher, this afternoon I'm an outreach worker: ethical dilemmas in practitioner research' International Journal of Social Research Methodology. Vol 9, No 5, p. 419-431.

David, M. (2009) Transforming Global Higher Education: A Feminist Perspective, London: Institute of Education.

David, M. Edwards, R. Hughes, M. Ribbens, J. (1993). Mothers and Education: Inside Out? Exploring Family-Education Policy and Experience London: The Macmillan Press Ltd.

Denzin, N.K., and Lincoln, Y.S. (Eds) (2005) Collecting and interpreting qualitative materials ( 3 ed) London: Sage.

Deer, C. (2008). 'Doxa' in, M Grenfell (Ed). Pierre Bourdieu: key concepts. Durham: Acumen.

Doucet, A. and Mauthner, N. (2013) 'Tea and Tupperware: Mommy Blogging as Care, Work, and 
Consumption' in C. Rogers and S. Weller (eds.) Critical Approaches to Care: Understanding caring relations, identities and cultures London, Routledge.

Ellis, C., and Bochner, A. (2000). Autoethnography, personal narrative, reflexivity: researcher as a subject. In: Denzin, N.K., and Lincoln, Y.S., (Eds). Handbook of qualitative research (2nd ed). London: Sage.

Ellis, C., Kiesinger, L., and Tillmann-Healy, L. (1997). Interactive interviewing: talking about emotional

experience. In Hertz, R., (Ed). Reflexivity and voice. London: Sage.

Gill, R. (2010). 'Breaking the silence: the hidden injuries of the neoliberal university'. In: Ryan-Flood, R., and Gill, R., (Eds). Secrecy and Silence in the Research Process: feminist reflections. London: Routledge.

Gillies, V. (2007) Marginalised mothers: Exploring working-class experiences of parenting. London: Routledge.

Grenfell, M., and James, D. (Eds). (1998). Bourdieu and theory: acts of practical theory. Abingdon:

RoutledgeFalmer.

Harding, S. (1986). The science question in feminism. New York: Cornell University Press.

Harding, S. (1991). Whose science? Whose knowledge? Thinking from women's lives. New York: Cornell University Press.

Harding, S. (1993). Rethinking standpoint epistemology: what is 'strong objectivity'? In: Alcoff, L., and Potter, E., (Eds). Feminist epistemologies. London: Routledge.

Hartstock, N.C.M. (1998). The feminist standpoint revisited. Oxford: Westview Press.

Held, V. (2006) The Ethics of Care: Personal, Political and Global Oxford, Oxford University Press.

Hertz, R. (Ed). (1997). Reflexivity and voice. London: Sage.

Hoskin, K. (1990) Foucault under examination: The crypto-educationalist unmasked. In: Ball, S.J. (Ed) Foucault and education: Disciplines and knowledge. London: Routledge.

Letherby, G. (2000). Dangerous liaisons: auto/biography in research and research writing. In: Lee-Treweek, G., and Linkogle, S. (Eds). Danger in the field: risks and ethics in social research. London: Routledge.

Letherby, G. (2003). Feminist research in theory and practice. Buckingham: Open University Press.

Lynch, K., Baker, J., and Lyons, M. (2009). Affective equality, love, care and injustice. Basingstoke: Palgrave Macmillan. 
Mauthner, M., Birch, M., Jessop, J., and Miller, T., (Eds) (2002) Ethics in qualitative research. London: Sage.

McRobbie, A. (2009). The aftermath of feminism: gender, culture and social change. London: Sage.

McNay, L. (1992). Foucault and Feminism. Cambridge: Polity Press.

Miller, T., and Bell, L. (2002) Consenting to what? Issues of access, gate-keeping and 'informed' consent. In Mauthner, M., Birch, M., Jessop, J., and Miller, T., (Eds). Ethics in qualitative research. London: Sage.

MUMSNET (2013) http://www.mumsnet.com/Talk/special_educational_needs.

Noddings, N. (2013). Caring: a feminine approach to ethics and moral education (2nd ed). California, USA: University of California Press.

O'Brien, K. (2010). 'Inside 'doorwork': gendering the security gaze'. In: RyanFlood, R., and Gill, R., (Eds). Secrecy and Silence in the Research Process: feminist reflections. London: Routledge.

Oakley, A. (2010). The social science of biographical life writing: some methodological and ethical issues. International Journal of Social Research Methodology. Vol 13, No 5, p. 425-439.

Oakley, A. (1981). Interviewing women. In: Roberts, H., (Ed). Doing feminist research. London: Routledge \& Kegan Paul Ltd.

Philip, G., Rogers, C., and Weller, S. (2013). 'Understanding Care and Thinking with Care'. In: Rogers, C., and Weller, S. (Eds). Critical Approaches to Care: Understanding caring relations, identities and cultures. London: Routledge.

Plummer, K. (2009) 'Introduction' Sexualities Vol 12: p. 268-269.

Puig de la Bellacasa, M. (2012). "Nothing comes without its world': thinking with care. The Sociological Review. Vol 60, No 2, p. 197-216.

Reay, D. (1996). Insider perspectives or stealing the words out of women's mouths: interpretation in the research process. Feminist Review. Vol 53, p. 57-73.

Reay, D. (2004). Gendering Bourdieu's concepts of capitals? Emotional capital, women and social class. The Sociological Review. Vol 53, p. 104-116.

Reay, D., and Arnot, M. (2007). A sociology of pedagogic voice: power, inequality and pupil consultation. Discourse: studies in the cultural politics of education. Vol 28, No 3, p. 311-325.

Reinharz, S. (1997). Who am I? The need for a variety of selves in the field. In: Hertz., R., (Ed). Reflexivity and voice. London: Sage.

Ribbens, J. (1998). Hearing my feeling voice? An autobiographical discussion of motherhood. In: Ribbens, J., and Edwards, R., (Eds). Feminist dilemmas in qualitative research: public knowledge and private lives. London: Sage. 
Ribbens, J., and Edwards, R. (Eds). (1998). Feminist dilemmas in qualitative research: public knowledge and private lives. London: Sage.

Ribbens McCarthy, J. (2013). Caring after death: issues of embodiment. In: Rogers, C., and Weller, S.

(Eds). Critical Approaches to Care: Understanding caring relations, identities and cultures. London:

Routledge.

Ribbens McCarthy, J., and Edwards, R. (2011). Key concepts in family studies. London: Sage.

Robbins, D. (1998). 'The need for an epistemological break' in M Grenfell and D James (Eds).

Bourdieu and theory: acts of practical theory. Abingdon: RoutledgeFalmer.

Robinson, F. (2011). The Ethics of Care: A Feminist Approach to Human Security Philadelphia, Temple

University Press.

Rogers, C. (2013a) 'Intellectual disability and mothering: an engagement with ethics of care and emotional work' in C, Rogers and S, Weller [eds.] Critical Approaches to Care: Understanding caring relations, identities and cultures London, Routledge.

Rogers, C (2013b) 'Mothering for life? Fractured maternal narratives, care and intellectual disability', in Bouvard, M. (ed.) Mothers of Adult Children, New York, Lexington Press.

Rogers, C. (2011) 'Mothering and intellectual disability: partnership rhetoric?' British Journal of Sociology of Education 32 (4) p. 563-581.

Rogers, C. (2009a) (S)excerpts from a life told: Sex, gender and learning disability Sexualities 12 (3) p. 270-288.

Rogers, C. (2009b) 'Hope as a mechanism in emotional survival: documenting miscarriage'. Auto/Biography Year Book 2009 Nottingham, Russell Press.

Rogers, C. (2007a) Parenting and Inclusive Education: discovering difference, experiencing difficulty. Houndmills, Palgrave Macmillan.

Rogers, C. (2007b) 'Experiencing an 'inclusive' education: Parents and their children with special educational needs (SEN)' British Journal of Sociology of Education 28 (1) p. 55-68.

Rogers, C. (2003) 'The mother/researcher in blurred boundaries of a reflexive research process', Auto/Biography XI (1\&2) p. 47-54.

Rogers, C., and Ludhra, G. (2011). 'Research ethics: participation, social difference and informed consent'. In:Bradford, S., and Cullen, F. (Eds). Research and research methods for youth practitioners. London: Routledge. 
Ryan-Flood, R. (2010). Keeping mum: secrecy and silence in research on lesbian parenthood. In: Ryan-Flood, R., and Gill, R., (Eds). Secrecy and silence in the research process: feminist reflections. London: Routledge.

Ryan-Flood, R. and Gill, R. (Eds). (2010). Secrecy and silence in the research process: feminist reflections. London: Routledge.

Sanger, T. (2010). Trans people's partnerships: towards an ethics of intimacy. Basingstoke: Palgrave Macmillan.

Skeggs, B. (1997). Formations of class and gender: becoming respectable. London: Sage.

Smart, C. (1990). Feminist approaches to criminology or postmodern woman meets atavistic man. In: Morris, A., and Gelsthorpe, L., (Eds). Feminist perspectives in criminology. Milton Keynes: Open University Press.

Tronto, J. C. (2011) 'A Feminist Democratic Ethics of Care and Global Care Workers: Citizenship and

Responsibility' in R Mahon and F Robinson, Feminist Ethics and Social Policy: Towards a New Global

Political Economy of Care Vancouver, UCB press.

Walby, S. (1999). New agendas for women. Basingstoke: MacMillan Press Ltd.

Walby, S. (2011). The future of feminism. Cambridge: Polity Press.

Walkerdine, V., Lucey, H., and Melody, J. (2001). Growing up girl: explorations of gender and class.

Basingstoke: Palgrave.

Woodthorpe, K. (2011). Researching death: methodological reflections on the management of critical distance. International Journal of Social Research Methodology. Vol 14, No 2, p. 99-109. 